\title{
Hereditary Human Prion Diseases: an Update
}

\author{
Matthias Schmitz ${ }^{1,2} \cdot$ Kathrin Dittmar $^{1} \cdot$ Franc Llorens $^{1} \cdot$ Ellen Gelpi $^{3} \cdot$ Isidre Ferrer $^{4}$. \\ Walter J. Schulz-Schaeffer ${ }^{2} \cdot$ Inga Zerr $^{1}$
}

Received: 5 January 2016/Accepted: 3 May 2016

(C) Springer Science+Business Media New York 2016

\begin{abstract}
Prion diseases in humans are neurodegenerative diseases which are caused by an accumulation of abnormal, misfolded cellular prion protein known as scrapie prion protein $\left(\mathrm{PrP}^{\mathrm{Sc}}\right)$. Genetic, acquired, or spontaneous (sporadic) forms are known. Pathogenic mutations in the human prion protein gene (PRNP) have been identified in 10-15\% of CJD patients. These mutations may be single point mutations, STOP codon mutations, or insertions or deletions of octapeptide repeats. Some non-coding mutations and new mutations in the PrP gene have been identified without clear evidence for their pathogenic significance. In the present review, we provide an updated overview of PRNP mutations, which have been documented in the literature until now, describe the change in the DNA, the family history, the pathogenicity, and the number of described cases, which has not been published in this complexity before. We also provide a description of each genetic prion disease type, present characteristic histopathological features, and the $\operatorname{PrP}^{\mathrm{Sc}}$ isoform expression pattern of various familial/genetic prion diseases.
\end{abstract}

Matthias Schmitz

matthias.schmitz@med.uni-goettingen.de

1 Department of Neurology, University Medical Center Göttingen and the German Center for Neurodegenerative Diseases (DZNE), Göttingen, Germany

2 Department of Neuropathology, Georg-August University, Göttingen, Robert-Koch-Str. 40, 37075 Göttingen, Germany

3 Neurological Tissue Bank, Biobanc-Hospital Clinic-IDIBAPS, Barcelona, Spain

4 Institute of Neuropathology, Bellvitge University Hospital, CIBERNED, Hospitalet de Llobregat, University of Barcelona, Barcelona, Spain
Keywords Hereditary human prion diseases · Creutzfeldt-Jakob disease $\cdot$ Fatal familial insomnia . Gerstmann-Sträussler-Scheinker syndrome

$\begin{array}{ll}\text { Abbreviations } \\ \text { FFI } & \text { Fatal familial insomnia } \\ \text { PRNP } & \text { Prion protein gene } \\ \text { PrP }^{\mathrm{Sc}} & \text { Scrapie prion protein } \\ \text { CJD } & \text { Creutzfeldt-Jakob disease } \\ \text { gCJD } & \text { Genetic CJD } \\ \text { SCJD } & \text { Sporadic CJD } \\ \text { OPRI } & \text { Octa-peptide repeat insertion } \\ \text { GSS } & \text { Gerstmann-Sträussler-Scheinker syndrome }\end{array}$

\section{Introduction}

Transmissible spongiform encephalopathies (TSE) or prion diseases are fatal neurodegenerative disorders, which are characterized by the aggregation and accumulation of misfolded scrapie prion protein $\left(\mathrm{PrP}^{\mathrm{Sc}}\right)$ in brain tissue. TSE can occur spontaneously (sporadic), hereditary or acquired, most as iatrogenic cases. Hereditary prion diseases are categorized by certain clinical and pathological features as familial CJD (fCJD), Gerstmann-Sträussler-Scheinker syndrome (GSS), or fatal familial insomnia (FFI). Since more than $50 \%$ of those cases have been reported without a family history, the term "genetic CJD (gCJD)" is now being used more frequently than "fCJD" [1]. Genetic CJD describes a single CJD case, where a mutation in the PrP gene seems to make the conversion into the abnormal form more likely. In some cases, it is difficult to decide whether the mutation is pathogenic or only a polymorphism. 
In contrast, in hereditary CJD or fCJD cases, the person has a family history of the disease and a positive test for a genetic mutation associated with CJD.

Since the sensitivity of most diagnostic tests (e.g., 14-3-3, RT-QuIC or MRI) is lower in some hereditary diseases such as FFI $[2,3]$ than in sporadic CJD (sCJD), a detailed clinical examination and clinical history is extremely important. A confirmed diagnosis of a hereditary prion disease requires the detection of a pathogenic PRNP mutation, a progressive neuropsychiatric disorder, and post mortem confirmation at autopsy [4].

The clinical onset of gCJD/fCJD usually occurs at an earlier age (between 30 and 70 years) compared to SCJD [5] and begins with memory impairment, confusion, myoclonus, and ataxia.

Several PRNP mutations (such as V210I or E200K) are associated with a variable disease onset and a heterogenic penetrance [6]. The penetrance of the disease increased with age, e.g., when mutation carriers survive to age over 80 years, the penetrance is almost $100 \%$ [7]. In contrast, at an age of 70 years, the penetrance is markedly decreased [7].

In sCJD patients, the methionine/valine (M/V) polymorphism at codon 129 of PRNP has a major influence on the susceptibility to and the progression of the disease [8-10]. Similar to sCJD, the clinicopathological phenotype in $\mathrm{gCJD} / \mathrm{fCJD}$ may also depend on the $\mathrm{M} / \mathrm{V}$ polymorphism at codon 129 of the mutated allele, e.g., in E200K carriers [11]. In octa-peptide repeat insertion (OPRI) mutation carriers, $P R N P$ codon $129 \mathrm{M} / \mathrm{M}$ carriers exhibit an earlier disease onset compared to $\mathrm{M} / \mathrm{V}$ carriers [5, 12]. However, in most of the genetic cases the influence of the PRNP codon 129 polymorphism on the clinicopathological phenotype has not yet been described well because of the rareness of the cases.

In certain PRNP mutations, e.g., D178N, the codon 129 polymorphism may even determine two completely distinct phenotypes. Traditionally, the 178 mutation in association with methionine at codon 129 has been termed FFI, while a coupling with valine at codon 129 causes different pathology, so that the disease was called fCJD [13]. In addition to the gene polymorphism in $P R N P$, more than 50 mutations in the open reading frame of $P R N P$ have been described.

In the present review, we provide an updated overview of the reported mutations, describe major differences in the $\operatorname{Pr} \mathrm{P}^{\mathrm{Sc}}$ expression profile, and present characteristic histopathological features of selected genetic prion diseases.

\section{Types of PRNP Mutations May Cause Different Kind of Prion Diseases}

The 253 amino acid PrP is encoded by the second exon of $P R N P$ [14]. All hereditary prion diseases are caused by a wide variety of mutations in the prion protein gene $(P R N P)$, which is located on the short (p) arm of chromosome 20 (20p12), $[15,16]$. All of these mutations are autosomal dominant. Among these mutations, point mutations in certain codons, multiple-point mutations, premature STOP codon mutations, or insertion/deletion of octa-peptide repeats in the N-terminal domain of PRNP have been reported [9, 17-19]. However, PRNP mutations also may appear spontaneously with an unknown family history or with an unknown phenotype.

\section{Hereditary CJD Caused by Point or Insert Mutations}

Genetic CJD can be caused by a variety of point mutations which are summarized in Table 1 or by insertional mutations in the octa-peptide region of PrP, summarized in Table 2 (Tables 1 and 2). The most common mutations in the European population are mutations at codons 178, 200, and 210. Clinically and neuropathologically E200K and V210I carriers resemble sCJD. The average age of onset is between 50 and 70 years of age, and the disease duration is often less than 6 months. The family history of V210I is relatively low (12\%) compared to E200K (49\%) [9].

In the E200K mutation carriers, immunohistochemical detection of $\operatorname{PrP}^{\mathrm{Sc}}$ aggregates usually show indistinguishable pattern from sCJD (MM1) cases (Fig. 1a); some cases show stripe-like deposits of $\mathrm{PrP}^{\mathrm{Sc}}$ in the molecular layer of the cerebellum (Fig. 1b, c) [127]. Biochemical typing revealed different types of $\mathrm{PrP}^{\mathrm{Sc}}$ which can be distinguished by the molecular weight (type 1 of $21 \mathrm{kDa}$, type 2 of $19 \mathrm{kDa}$ ) of the unglycosylated PrP isoform. V210I and E200K codon 129 $\mathrm{MM}$ carriers show a similar composition of the $\mathrm{PrP}^{\mathrm{Sc}}$ isoform pattern, consisting of di-, mono-, and unglycosylated $\operatorname{PrP}$ (Fig. 4b). The PrP pattern is comparable to that of sCJD (MM1) patients (Fig. 4b). $\operatorname{PrP}^{\mathrm{Sc}}$ type 1 is typically associated with fCJD E200K and V210I (PRNP codon 129 MM), while $\mathrm{PrP}^{\mathrm{Sc}}$ type 2 is associated with fCJD E200K codon $129 \mathrm{VV}$ (Fig. 4b).

\section{Hereditary CJD Caused by STOP Codon Mutations}

Some point mutations integrate a stop codon at different positions within PRNP resulting in the production of abnormal, truncated forms of PrP. STOP codon mutations are very rare in inherited prion diseases and they are accompanied by unusual phenotypes. Examples of STOP mutations are Y145X (tangle pathology), Q160X, Y163X, Y226X, or Q227X [18, 42, 46, 128]. Of these PRNP STOP mutations, Q160X and Q227X cause an Alzheimer disease-like pathology with either amyloid plaques, neurofibrillary tangle lesions, or both [18, 128]. 
Table 1 Overview of prion disease-associated point mutations

\begin{tabular}{|c|c|c|c|c|c|c|c|c|}
\hline Codon & $\begin{array}{l}\text { Change } \\
\text { in DNA }\end{array}$ & $\begin{array}{l}\text { Familial } \\
\text { history }\end{array}$ & Pathologic & $>1$ case & $\begin{array}{l}\text { Change in } \\
\text { amino acid }\end{array}$ & $\begin{array}{l}\text { PRNP } \\
\text { codon } 129\end{array}$ & Disease & Reference \\
\hline 39 & $\operatorname{ccg} \rightarrow \operatorname{ctg}$ & n.d. & n.d. & n.d. & Pro $\rightarrow$ Leu & n.d. & FTLD & {$[20,21]$} \\
\hline 52 & n.d. & n.d. & n.d. & No & Gln $\rightarrow$ Pro & MV & Atypical CJD & {$[22]$} \\
\hline 54 & ggt $\rightarrow$ agt & No & No & Yes & Gly $\rightarrow$ Ser & MM & n.d. & {$[23]$} \\
\hline 84 & n.d. & n.d. & Yes & Yes & Pro $\rightarrow$ Ser & MV & GSS & {$[24]$} \\
\hline 97 & agt $\rightarrow$ aat & n.d. & n.d. & n.d. & Ser $\rightarrow$ Asn & MM & Probable AD & {$[25]$} \\
\hline 102 & $\operatorname{ccg} \rightarrow \operatorname{ctg}$ & n.d. & Yes & Yes & Pro $\rightarrow$ Leu & MM & GSS & {$[26,27]$} \\
\hline 105 & $\mathrm{cca} \rightarrow \mathrm{cta}$ & Yes & Yes & Yes & Pro $\rightarrow$ Leu & VV & GSS & [28] \\
\hline 105 & $\mathrm{cca} \rightarrow \mathrm{aca}$ & n.d. & n.d. & No & Pro $\rightarrow$ Thr & VV & GSS & [29] \\
\hline 105 & $\mathrm{cca} \rightarrow \mathrm{tca}$ & n.d. & n.d. & n.d. & Pro $\rightarrow$ Ser & VV & GSS & {$[30]$} \\
\hline 114 & $\mathrm{ggt} \rightarrow \mathrm{gtt}$ & n.d. & Yes & Yes & Gly $\rightarrow$ Val & MM, MV & gCJD & {$[31]$} \\
\hline 117 & gca $\rightarrow$ gtg & Yes & Yes & Yes & $\mathrm{Ala} \rightarrow \mathrm{Val}$ & VV & GSS & {$[32,33]$} \\
\hline 127 & $\mathrm{ggc} \rightarrow \mathrm{gtc}$ & n.d. & n.d. & n.d. & Gly $\rightarrow$ Val & MM & $\begin{array}{l}\text { Protective } \\
\text { against Kuru }\end{array}$ & [34-36] \\
\hline 131 & gga $\rightarrow$ gta & n.d. & Yes & Yes & Gly $\rightarrow$ Val & MM, MV & GSS & {$[37,38]$} \\
\hline 132 & agt $\rightarrow$ att & n.d. & n.d. & n.d. & $\mathrm{Ser} \rightarrow \mathrm{Ile}$ & MM & GSS & [39] \\
\hline 133 & gca $\rightarrow$ gtg & No & n.d. & Yo & $\mathrm{Ala} \rightarrow \mathrm{Val}$ & MM & GSS & {$[40]$} \\
\hline 142 & $\mathrm{ggc} \rightarrow \mathrm{agc}$ & n.d. & n.d. & Yes & Gly $\rightarrow$ Ser & MM, MV & n.d. & [23] \\
\hline 145 & tat $\rightarrow$ tag & n.d. & Yes & n.d. & $\mathrm{Tyr} \rightarrow$ Stop & MM & GSS, AD & {$[41,42]$} \\
\hline 148 & cgt $\rightarrow$ cat & Yes & Yes & Yes & $\mathrm{Arg} \rightarrow \mathrm{His}$ & MM & fCJD & [43] \\
\hline 160 & $\mathrm{caa} \rightarrow$ taa & Yes & Yes & Yes & Gln $\rightarrow$ Stop & MM, MV & Dementia & [44] \\
\hline 163 & tat $\rightarrow$ tag & n.d. & n.d. & Yes & $\mathrm{Tyr} \rightarrow$ Stop & VV & GSS & [45-47] \\
\hline 167 & gat $\rightarrow$ aat & n.d. & n.d. & n.d. & Asp $\rightarrow$ Asn & n.d. & n.d. & [23] \\
\hline 167 & gat $\rightarrow$ ggt & n.d. & n.d. & n.d. & Asp $\rightarrow$ Gly & MM & n.d. & [23] \\
\hline 171 & $\mathrm{aac} \rightarrow \mathrm{agc}$ & n.d. & n.d. & No & Asn $\rightarrow$ Ser & $\mathrm{MV}, \mathrm{VV}$ & Unknown & [48] \\
\hline 173 & $\mathrm{aac} \rightarrow \mathrm{aag}$ & n.d. & n.d. & n.d. & Asn $\rightarrow$ Lys & MV & n.d. & {$[22]$} \\
\hline 176 & gtg $\rightarrow$ ggg & n.d. & Yes & No & Val $\rightarrow$ Gly & VV & Unusual GSS & [49] \\
\hline $178-129 \mathrm{~V}$ & $\mathrm{gac} \rightarrow \mathrm{aac}$ & Yes & n.d. & Yes & Asp $\rightarrow$ Asn & VV & fCJD & {$[50,51]$} \\
\hline $178-129 \mathrm{M}$ & $\mathrm{gac} \rightarrow \mathrm{aac}$ & n.d. & n.d. & Yes & Asp $\rightarrow$ Asn & MM & FFI & {$[52]$} \\
\hline 180 & $\mathrm{gtc} \rightarrow$ atc & n.d. & Yes & Yes & $\mathrm{Val} \rightarrow \mathrm{Ile}$ & MM & gCJD & {$[53,54]$} \\
\hline 183 & $\mathrm{aca} \rightarrow$ acg & Yes & Yes & Yes & $\mathrm{Thr} \rightarrow$ Ala & MM & fCJD & {$[55]$} \\
\hline 187 & $\mathrm{cac} \rightarrow \mathrm{cgc}$ & Yes & Yes & Yes & His $\rightarrow$ Arg & VV & Probable GSS & {$[56,57]$} \\
\hline 188 & acg $\rightarrow$ aag & n.d. & Yes & Yes & Thr $\rightarrow$ Lys & n.d. & gCJD & {$[44,58]$} \\
\hline 188 & $\operatorname{acg} \rightarrow \operatorname{gcg}$ & n.d. & Yes & Yes & $\mathrm{Thr} \rightarrow$ Ala & MM & gCJD & [59] \\
\hline 188 & $\operatorname{acg} \rightarrow$ agg & n.d. & Yes & Yes & $\mathrm{Thr} \rightarrow \operatorname{Arg}$ & VV & $\begin{array}{l}\text { Criteria for CJD } \\
\text { are not fulfilled }\end{array}$ & {$[19,60]$} \\
\hline 193 & $\mathrm{acc} \rightarrow \mathrm{att}$ & n.d. & n.d. & No & $\mathrm{Thr} \rightarrow$ Ile & MM & Probable CJD & {$[61]$} \\
\hline 196 & gag $\rightarrow$ aag & Yes & Yes & Yes & Glu $\rightarrow$ Lys & MM, MV & fCJD & {$[62]$} \\
\hline 196 & gag $\rightarrow$ gcg & n.d. & Yes & No & Glu $\rightarrow$ Ala & n.d. & gCJD & [63] \\
\hline 198 & $\mathrm{ttc} \rightarrow \mathrm{gtc}$ & n.d. & n.d. & No & $\mathrm{Phe} \rightarrow \mathrm{Val}$ & VV, MM & Probable AD & {$[25]$} \\
\hline 198 & $\mathrm{ttc} \rightarrow \mathrm{tcc}$ & Yes & Yes & Yes & $\mathrm{Phe} \rightarrow$ Ser & MV & GSS & {$[64,65]$} \\
\hline 200 & gag $\rightarrow$ aag & n.d. & n.d. & Yes & Glu $\rightarrow$ Lys & MV & fCJD & {$[66]$} \\
\hline 200 & gag $\rightarrow$ ggg & n.d. & Yes & No & Glu $\rightarrow$ Gly & MV & fCJD & {$[67]$} \\
\hline 202 & $\mathrm{gac} \rightarrow \mathrm{aac}$ & n.d. & Yes & n.d. & Asp $\rightarrow$ Asn & VV & GSS & {$[68]$} \\
\hline 202 & $\mathrm{gac} \rightarrow \mathrm{ggc}$ & n.d. & n.d. & No & Asp $\rightarrow$ Gly & VV & $\begin{array}{l}\text { Slow progressive dementia } \\
\text { syndrome }\end{array}$ & [69] \\
\hline 203 & $\mathrm{gtt} \rightarrow \mathrm{att}$ & n.d. & Yes & Yes & $\mathrm{Val} \rightarrow \mathrm{Ile}$ & $\mathrm{MM}$ & gCJD & {$[62,70]$} \\
\hline 203 & $\mathrm{gtt} \rightarrow \mathrm{ggt}$ & n.d. & n.d. & n.d. & $\mathrm{Val} \rightarrow$ Gly & n.d. & Probable fCJD & {$[22]$} \\
\hline 208 & $\mathrm{cgc} \rightarrow \mathrm{cac}$ & No & Yes & Yes & $\mathrm{Arg} \rightarrow \mathrm{His}$ & MM & gCJD & {$[71,72]$} \\
\hline 208 & $\operatorname{cgc} \rightarrow \operatorname{tgc}$ & n.d. & n.d. & No & $\mathrm{Arg} \rightarrow \mathrm{Cys}$ & MM & Probable AD & {$[25]$} \\
\hline
\end{tabular}


Table 1 (continued)

\begin{tabular}{lllllllll}
\hline Codon & $\begin{array}{l}\text { Change } \\
\text { in DNA }\end{array}$ & $\begin{array}{l}\text { Familial } \\
\text { history }\end{array}$ & Pathologic & $>1$ case & $\begin{array}{l}\text { Change in } \\
\text { amino acid }\end{array}$ & $\begin{array}{l}\text { PRNP } \\
\text { codon 129 }\end{array}$ & Disease & Reference \\
\hline 209 & gtg $\rightarrow$ atg & n.d. & n.d. & No & Val $\rightarrow$ Met & VV & n.d. & [23] \\
210 & gtt $\rightarrow$ att & Yes & Yes & Yes & Val $\rightarrow$ Ile & MM & fCJD & [73, 74] \\
211 & gag $\rightarrow$ cag & Yes & Possible & Yes & Glu $\rightarrow$ Gln & MM & fCJD & [62, 75] \\
211 & gag $\rightarrow$ gac & n.d. & n.d. & n.d. & Glu $\rightarrow$ Asp & VV & gCJD & [76] \\
212 & cag $\rightarrow$ ccg & n.d. & Yes & n.d. & Gln $\rightarrow$ Pro & MM, VV & GSS & [23] \\
215 & atc $\rightarrow$ gtc & Yes & Yes & Yes & Ile $\rightarrow$ Val & MM & fCJD & [77] \\
217 & cag $\rightarrow$ cgg & Yes & Yes & Yes & Gln $\rightarrow$ Arg & VV & GSS & [78] \\
218 & tac $\rightarrow$ aac & Yes & Yes & Yes & Tyr $\rightarrow$ Asn & VV & GSS & [79] \\
219 & gag $\rightarrow$ aag & n.d. & n.d. & Yes & Glu $\rightarrow$ Lys & MM & GSS & [80, 81] \\
226 & tac $\rightarrow$ taa & No & Yes & No & Tyr $\rightarrow$ Stop & VV & GSS & [18, 80, 81] \\
227 & cag $\rightarrow$ tag & No & Yes & No & Gln $\rightarrow$ Stop & VV & GSS & fCJD
\end{tabular}

Details about the gene codon, change in DNA sequence, familial history, pathology, number of cases, change in amino acid sequence, type of disease, and corresponding reference are indicated for each PRNP mutation. Lacking information is marked as not-described (n.d.)

Further characteristic phenotypes such a cerebral amyloidosis can be observed in Y145X and Y226X carriers [18, 42], while $\mathrm{Y} 163 \mathrm{X}$ is accompanied by chronic diarrhea with dysautonomia [46], suggesting a variable phenotype of certain PRNP mutation which is not always typical for a prion disease.

\section{Insertion Mutations}

Human PRNP consists of a nona-peptide (PQGGGTWGQ) followed by a tandem repeat of four copies of an octapeptide (PHGGGWGQ). These repeats are located between amino acid residues 51 and 91 . The normal structure of the five repeats has been designated R1-R2-R2-R3-R4. R1 encodes a nona-peptide, while $\mathrm{R} 2$ to $\mathrm{R} 4$ encode octa-peptides of the formula $\mathrm{P}(\mathrm{H} / \mathrm{Q}) \mathrm{GGG}(-/ \mathrm{G}) \mathrm{WGQ}$.

By non-coding nucleotide differences, R2, R3, and R4 are each distinguished from R1. Patients with an octa-peptide repeat insertion (OPRI) may have either one or up to 12 additional octa-repeats in PRNP (Table 2). The cause of this extra repeat formation might be an unequal crossover and recombination [17].

The clinical picture of this group of patients $(>30$ cases) may range from that of classical CJD to that of a GSS-type illness of long duration [129]. In most cases, there is a correlation between the length of the inserts, the age of onset and the duration of the disease. With an increase in the insert numbers from one to seven, the duration of the illness can range from 5 to 120 months
[15]. The majority of the patients have a chronic course with aphasia, apraxia, cerebral ataxia, extrapyramidal features, and memory loss [17, 116, 119]. However, patients with one, two, or four extra repeats may have a phenotype similar to SCJD [5]. The clinical pathological features of patients with five, six, seven, eight, and nine extra repeats are reminiscent of Gerstmann-Sträussler-Scheinker syndrome or atypical dementia [93, 130].

In octa-peptide repeat insertion patients, immunohistochemical detection of $\mathrm{PrP}^{\mathrm{Sc}}$ aggregates usually show a patchy or tigroid pattern (Fig. 1d-h). Additionally, they may show coarse and plaque-like $\operatorname{PrP}^{\mathrm{Sc}}$ deposits (Fig. 1g, in case of 4 OPRI) or a tigroid pattern (Fig. 1h, 5 OPRI) in the cerebellar cortex. The $\mathrm{PrP}^{\mathrm{Sc}}$ aggregate pattern indicates a similar pattern comparable to sCJD VV2 patients (Fig. 1i). Most of the OPRI patients express the proteinase $\mathrm{K}$-resistant $\mathrm{PrP}^{\mathrm{Sc}}$ type 2 (Fig. 4b) according to the system described by Parchi et al. [10]. In single cases, $\mathrm{PrP}^{\mathrm{Sc}}$ type 1 may be expressed, as shown for a 4-OPRI codon 129 MM (Fig. 4b).

\section{FFI-Related Mutations}

FFI, the most common genetic prion disease worldwide, typically begins with sleep and vigilance disturbances, cognitive deficits, spatial disorientation, hallucinations, autonomic disturbance, and motoric signs with an onset between 36 and 62 years (average: 56 years). FFI was reported initially as thalamic dementia [131, 132]. The duration of the disease depends on the codon $129 \mathrm{MV}$ polymorphism and is between 
Table 2 Overview of octa-peptide repeat deletion/insertion (OPRI) mutations

\begin{tabular}{|c|c|c|c|c|c|c|}
\hline Coding change & Insert & Sequence & $\begin{array}{l}P R N P \\
\text { codon } 129\end{array}$ & Disease & $>1$ cases & Reference \\
\hline None & No & $\mathrm{R} 1, \mathrm{R} 2, \mathrm{R} 2, \mathrm{R} 3, \mathrm{R} 4$ & All & None & n.d. & {$[17]$} \\
\hline 24 bp deletion & -1 & $\mathrm{R} 2$ or $\mathrm{R} 2, \mathrm{R} 3$ or $\mathrm{R} 2, \mathrm{R} 4$ & MM & None & n.d. & {$[85]$} \\
\hline $24 \mathrm{bp}$ insertion & 1 & $\mathrm{R} 1, \mathrm{R} 2, \mathrm{R} 2, \mathrm{R} 2, \mathrm{R} 3, \mathrm{R} 4$ & n.d. & n.d. & n.d. & [86] \\
\hline $48 \mathrm{bp}$ insertion & 2 & 2R1,R2,R2,R3,R2a,R2a,R4 & $\mathrm{MM}$ & fCJD-like & Yes & [87] \\
\hline $48 \mathrm{bp}$ insertion & 2 & R1,R2, R2a,R2,R2a,R2a,R4 & VV & n.d. & No & [88] \\
\hline $48 \mathrm{bp}$ insertion & 2 & $\mathrm{R} 1, \mathrm{R} 2, \mathrm{R} 2 \mathrm{a}, \mathrm{R} 2, \mathrm{R} 2 \mathrm{a}, \mathrm{R} 2 \mathrm{a}, \mathrm{R} 4$ & MV & Dementia & n.d. & [89] \\
\hline $72 \mathrm{bp}$ insertion & 3 & $\mathrm{R} 1, \mathrm{R} 2, \mathrm{R} 2, \mathrm{R} 3 \mathrm{~g}, \mathrm{R} 2, \mathrm{R} 2, \mathrm{R} 3, \mathrm{R} 4$ & VV & $\mathrm{gCJD}$ & n.d. & [90] \\
\hline 72 bp insertion & 3 & $\mathrm{R} 1, \mathrm{R} 2, \mathrm{R} 2, \mathrm{R} 2 \mathrm{a}, \mathrm{R} 2, \mathrm{R} 2, \mathrm{R} 3, \mathrm{R} 4$ & MM & Still healthy & n.d. & [91] \\
\hline $72 \mathrm{bp}$ insertion & 3 & $\mathrm{R} 1, \mathrm{R} 2, \mathrm{R} 2, \mathrm{R} 3 \mathrm{~g}, \mathrm{R} 2, \mathrm{R} 2, \mathrm{R} 3, \mathrm{R} 4$ & MM & Probable fCJD & n.d. & [92] \\
\hline $96 \mathrm{bp}$ insertion & 4 & $\mathrm{R} 1, \mathrm{R} 2, \mathrm{R} 2, \mathrm{R} 3 \mathrm{~g}, \mathrm{R} 2, \mathrm{R} 3 \mathrm{~g}, \mathrm{R} 2, \mathrm{R} 3, \mathrm{R} 4$ & MM & gCJD & n.d. & [93] \\
\hline $96 \mathrm{bp}$ insertion & 4 & $\mathrm{R} 2, \mathrm{R} 3, \mathrm{R} 2, \mathrm{R} 3$ & MM & n.d. & n.d. & [17] \\
\hline $96 \mathrm{bp}$ insertion & 4 & $\mathrm{R} 1, \mathrm{R} 2(6), \mathrm{R} 3, \mathrm{R} 4$ & MM & gCJD & n.d. & [94] \\
\hline $96 \mathrm{bp}$ insertion & 4 & $\mathrm{R} 1, \mathrm{R} 2, \mathrm{R} 2, \mathrm{R} 3, \mathrm{R} 2, \mathrm{R} 2, \mathrm{R} 2, \mathrm{R} 3, \mathrm{R} 4$ & VV & gCJD & n.d. & [86] \\
\hline 96 bp insertion & 4 & n.d. & MM & gCJD & n.d. & [12] \\
\hline $96 \mathrm{bp}$ insertion & 4 & $\mathrm{R} 1, \mathrm{R} 2, \mathrm{R} 2, \mathrm{R} 3, \mathrm{R} 2, \mathrm{R} 2, \mathrm{R} 2, \mathrm{R} 3, \mathrm{R} 4$ & MV & gCJD & n.d. & [95] \\
\hline $96 \mathrm{bp}$ insertion & 4 & $\mathrm{R} 1, \mathrm{R} 2, \mathrm{R} 2, \mathrm{R} 2, \mathrm{R} 3, \mathrm{R} 2, \mathrm{R} 2, \mathrm{R} 3, \mathrm{R} 4$ & $\mathrm{MM}$ & Dementia & n.d. & [96] \\
\hline 120 bp insertion & 5 & $\mathrm{R} 1, \mathrm{R} 2(2), \mathrm{R} 3, \mathrm{R} 2, \mathrm{R} 3 \mathrm{~g}, \mathrm{R} 2(2), \mathrm{R} 3, \mathrm{R} 4$ & n.d. & fCJD & Yes & {$[17]$} \\
\hline $120 \mathrm{bp}$ insertion & 5 & $\mathrm{R} 1, \mathrm{R} 2(2), \mathrm{R} 3, \mathrm{R} 2, \mathrm{R} 2, \mathrm{R} 2, \mathrm{R} 2, \mathrm{R} 3, \mathrm{R} 4$ & $\mathrm{MM}$ & fCJD & Yes & [97] \\
\hline 120 bp insertion & 5 & n.d. & MM & Atypical fCJD & n.d. & [98] \\
\hline $120 \mathrm{bp}$ insertion & 5 & $\mathrm{R} 1, \mathrm{R} 2, \mathrm{R} 2, \mathrm{R} 3 \mathrm{~g}, \mathrm{R} 3 \mathrm{~g}, \mathrm{R} 3 \mathrm{~g}, \mathrm{R} 2, \mathrm{R} 2, \mathrm{R} 3, \mathrm{R} 4$ & MV & fCJD & Yes & [99] \\
\hline $120 \mathrm{bp}$ insertion & 5 & $\mathrm{R} 1, \mathrm{R} 2, \mathrm{R} 3, \mathrm{R} 2, \mathrm{R} 3, \mathrm{R} 2, \mathrm{R} 3 \mathrm{~g}, \mathrm{R} 2, \mathrm{R} 3, \mathrm{R} 4$ & MM & n.d. & n.d. & {$[100]$} \\
\hline 144 bp insertion & 6 & $\mathrm{R} 1, \mathrm{R} 2, \mathrm{R} 2, \mathrm{R} 2, \mathrm{R} 3, \mathrm{R} 2, \mathrm{R} 3 \mathrm{~g}, \mathrm{R} 2, \mathrm{R} 2, \mathrm{R} 3, \mathrm{R} 4$ & MM & n.d. & Yes & {$[101]$} \\
\hline 144 bp insertion & 6 & n.d. & n.d. & gCJD & n.d. & {$[102]$} \\
\hline 144 bp insertion & 6 & R1,R2(3),R3,R2,R3g,R2(2),R3,R4 & n.d. & n.d. & n.d. & {$[103]$} \\
\hline 144 bp insertion & 6 & $\mathrm{R} 1, \mathrm{R} 2(2), \mathrm{R} 3 \mathrm{~g}, \mathrm{R} 2(2), \mathrm{R} 3 \mathrm{~g}, \mathrm{R} 2(2), \mathrm{R} 3, \mathrm{R} 4$ & MM & fCJD & Yes & {$[104]$} \\
\hline 144 bp insertion & 6 & $\mathrm{R} 1, \mathrm{R} 2, \mathrm{R} 2, \mathrm{R} 3, \mathrm{R} 2, \mathrm{R} 3 \mathrm{~g}, \mathrm{R} 2, \mathrm{R} 3 \mathrm{~g}, \mathrm{R} 2, \mathrm{R} 3, \mathrm{R} 4$ & n.d. & fCJD & Yes & {$[105]$} \\
\hline 144 bp insertion & 6 & $\mathrm{R} 1, \mathrm{R} 2, \mathrm{R} 2, \mathrm{R} 2(6), \mathrm{R} 3, \mathrm{R} 4$ & MV & fCJD & Yes & {$[106]$} \\
\hline 144 bp insertion & 6 & $\mathrm{R} 1, \mathrm{R} 2, \mathrm{R} 2,[\mathrm{R} 3, \mathrm{R} 2, \mathrm{R} 3 \mathrm{~g}, \mathrm{R} 2, \mathrm{R} 2, \mathrm{R} 2], \mathrm{R} 3, \mathrm{R} 4$ & MV & GSS & n.d. & {$[107]$} \\
\hline 144 bp insertion & 6 & $\mathrm{R} 1, \mathrm{R} 2, \mathrm{R} 2, \mathrm{R} 3, \mathrm{R} 2, \mathrm{R} 3 \mathrm{~g}, \mathrm{R} 3, \mathrm{R} 2, \mathrm{R} 2, \mathrm{R} 3, \mathrm{R} 4$ & n.d. & gCJD & n.d. & [9] \\
\hline 144 bp insertion & 6 & $\mathrm{R} 1, \mathrm{R} 2, \mathrm{R} 2, \mathrm{R} 3 \mathrm{~g}, \mathrm{R} 3, \mathrm{R} 4$ & n.d. & $\mathrm{gCJD}$ & n.d. & [108] \\
\hline $168 \mathrm{bp}$ insertion & 7 & $\mathrm{R} 1, \mathrm{R} 2, \mathrm{R} 2 \mathrm{c}, \mathrm{R} 3, \mathrm{R} 2, \mathrm{R} 3, \mathrm{R} 2, \mathrm{R} 3, \mathrm{R} 2, \mathrm{R} 3 \mathrm{~g}, \mathrm{R} 3, \mathrm{R} 4$ & n.d. & gCJD & n.d. & [109] \\
\hline $168 \mathrm{bp}$ insertion & 7 & R2,R2,R2,R2,R3g,R2,R2 & VV & gCJD & n.d. & [38] \\
\hline 168 bp insertion & 7 & $\mathrm{R} 1, \mathrm{R} 2, \mathrm{R} 2, \mathrm{R} 2, \mathrm{R} 2, \mathrm{R} 2, \mathrm{R} 3 \mathrm{~g}, \mathrm{R} 2, \mathrm{R} 3 \mathrm{~g}, \mathrm{R} 2 \mathrm{a}, \mathrm{R} 3, \mathrm{R} 4$ & MM & $\mathrm{gCJD}$ & n.d. & {$[110]$} \\
\hline 168 bp insertion & 7 & $\mathrm{R} 1, \mathrm{R} 2, \mathrm{R} 2, \mathrm{R} 3, \mathrm{R} 2, \mathrm{R} 2, \mathrm{R} 3 \mathrm{~g}, \mathrm{R} 2, \mathrm{R} 2, \mathrm{R} 2, \mathrm{R} 3, \mathrm{R} 4$ & MM & gCJD & n.d. & {$[111]$} \\
\hline $168 \mathrm{bp}$ insertion & 7 & $\mathrm{R} 1, \mathrm{R} 2, \mathrm{R} 2, \mathrm{R} 3, \mathrm{R} 2, \mathrm{R} 2, \mathrm{R} 3 \mathrm{~g}, \mathrm{R} 2, \mathrm{R} 2, \mathrm{R} 2, \mathrm{R} 3, \mathrm{R} 4$ & MM & GSS & n.d. & {$[112]$} \\
\hline $168 \mathrm{bp}$ insertion & 7 & $\mathrm{R} 1, \mathrm{R} 2, \mathrm{R} 2, \mathrm{R} 3, \mathrm{R} 2, \mathrm{R} 2, \mathrm{R} 2, \mathrm{R} 3 \mathrm{~g}, \mathrm{R} 2, \mathrm{R} 2, \mathrm{R} 3, \mathrm{R} 4$ & n.d. & Dementia & n.d. & {$[113]$} \\
\hline $168 \mathrm{bp}$ insertion & 7 & $\mathrm{R} 1, \mathrm{R} 2, \mathrm{R} 2, \mathrm{R} 3, \mathrm{R} 2, \mathrm{R} 3, \mathrm{R} 2, \mathrm{R} 2, \mathrm{R} 2, \mathrm{R} 2, \mathrm{R} 3, \mathrm{R} 4$ & n.d. & $\begin{array}{l}\text { Spongiform } \\
\text { encephalopathy }\end{array}$ & n.d. & [114] \\
\hline 192-bp insertion & 8 & $\mathrm{R} 1, \mathrm{R} 2, \mathrm{R} 2, \mathrm{R} 3, \mathrm{R} 2(7), \mathrm{R} 2 \mathrm{a}, \mathrm{R} 4$ & $\mathrm{VV}$ & GSS & Yes & {$[115]$} \\
\hline 192 bp insertion & 8 & not described in detail & VV & GSS & Yes & {$[116]$} \\
\hline 192-bp insertion & 8 & $\mathrm{R} 1, \mathrm{R} 2, \mathrm{R} 2, \mathrm{R} 3, \mathrm{R} 2, \mathrm{R} 2, \mathrm{R} 2, \mathrm{R} 2 \mathrm{a}, \mathrm{R} 2, \mathrm{R} 2, \mathrm{R} 2, \mathrm{R} 3, \mathrm{R} 4$ & MM & GSS & Yes & {$[117]$} \\
\hline 192 bp insertion & 8 & $\mathrm{R} 1, \mathrm{R} 2, \mathrm{R} 2, \mathrm{R} 3 \mathrm{~g}, \mathrm{R} 2, \mathrm{R} 2, \mathrm{R} 2, \mathrm{R} 3 \mathrm{~g}, \mathrm{R} 3 \mathrm{~g}, \mathrm{R} 2, \mathrm{R} 2, \mathrm{R} 3, \mathrm{R} 4$ & n.d. & $\mathrm{HD}$ & Yes & {$[118]$} \\
\hline 216 bp insertion & 9 & not described in detail & MM & GSS & n.d. & [119] \\
\hline 216 bp insertion & 9 & $\mathrm{R} 1, \mathrm{R} 2, \mathrm{R} 2, \mathrm{R} 3, \mathrm{R} 2 \mathrm{R} 3, \mathrm{R} 3 \mathrm{~g}, \mathrm{R} 2, \mathrm{R} 2 \mathrm{a}, \mathrm{R} 2, \mathrm{R} 3, \mathrm{R} 2, \mathrm{R} 3, \mathrm{R} 4$ & MM & GSS & n.d. & {$[120]$} \\
\hline $216 \mathrm{bp}$ insertion & 9 & $\mathrm{R} 1, \mathrm{R} 2, \mathrm{R} 2, \mathrm{R} 3, \mathrm{R} 2, \mathrm{R} 3 \mathrm{~g}, \mathrm{R} 2 \mathrm{a}, \mathrm{R} 2, \mathrm{R} 2, \mathrm{R} 2, \mathrm{R} 3 \mathrm{~g}, \mathrm{R} 2, \mathrm{R} 3, \mathrm{R} 4$ & n.d. & Dementia & n.d. & {$[121]$} \\
\hline 216 bp insertion & 9 & $\mathrm{R} 1, \mathrm{R} 2 \mathrm{a}, \mathrm{R} 2(3), \mathrm{R} 3, \mathrm{R} 2(6), \mathrm{R} 3, \mathrm{R} 4$ & MM & Sporadic dementia & n.d. & {$[122]$} \\
\hline $288 \mathrm{bp}$ insertion & 12 & $\begin{array}{l}\mathrm{R} 1, \mathrm{R} 2, \mathrm{R} 2, \mathrm{R} 3, \mathrm{R} 2, \mathrm{R} 2, \mathrm{R} 3, \mathrm{R} 2, \mathrm{R} 3 \mathrm{~g}, \mathrm{R} 2, \mathrm{R} 3 \mathrm{~g}, \mathrm{R} 2, \mathrm{R} 2, \\
\mathrm{R} 3 \mathrm{~g}, \mathrm{R} 2, \mathrm{R} 3, \mathrm{R} 4\end{array}$ & n.d. & FTD & n.d. & {$[123]$} \\
\hline
\end{tabular}

Details about the coding change, number of inserts, sequence change, codon 129 genotype, kind of disease, number of cases, and corresponding reference are indicated for each $P R N P$ mutation. Lacking information is marked as not-described (n.d.)

6 and 72 months with an average duration of approximately 11 months in MM cases while MV cases exhibit an average disease duration of 23 months [3, 52, 133-135]. However, opposed to the first reported FFI patients, more recent studies indicated that the clinical course of patients with a FFI mutation resembled sCJD without any insomnia symptoms. These observations challenge the widely accepted assumption that codon $129 \mathrm{MM}$ homozygosity is always related to a FFI phenotype $[135,136]$.

Typically, FFI patients exhibit severe neuronal loss in the anterior ventral and mediodorsal thalamic nuclei and the inferior olivary nucleus associated with prominent astrogliosis and microglial activation (Fig. 2a, b). In the cerebellum, extensive Purkinje cell loss can be observed frequently 

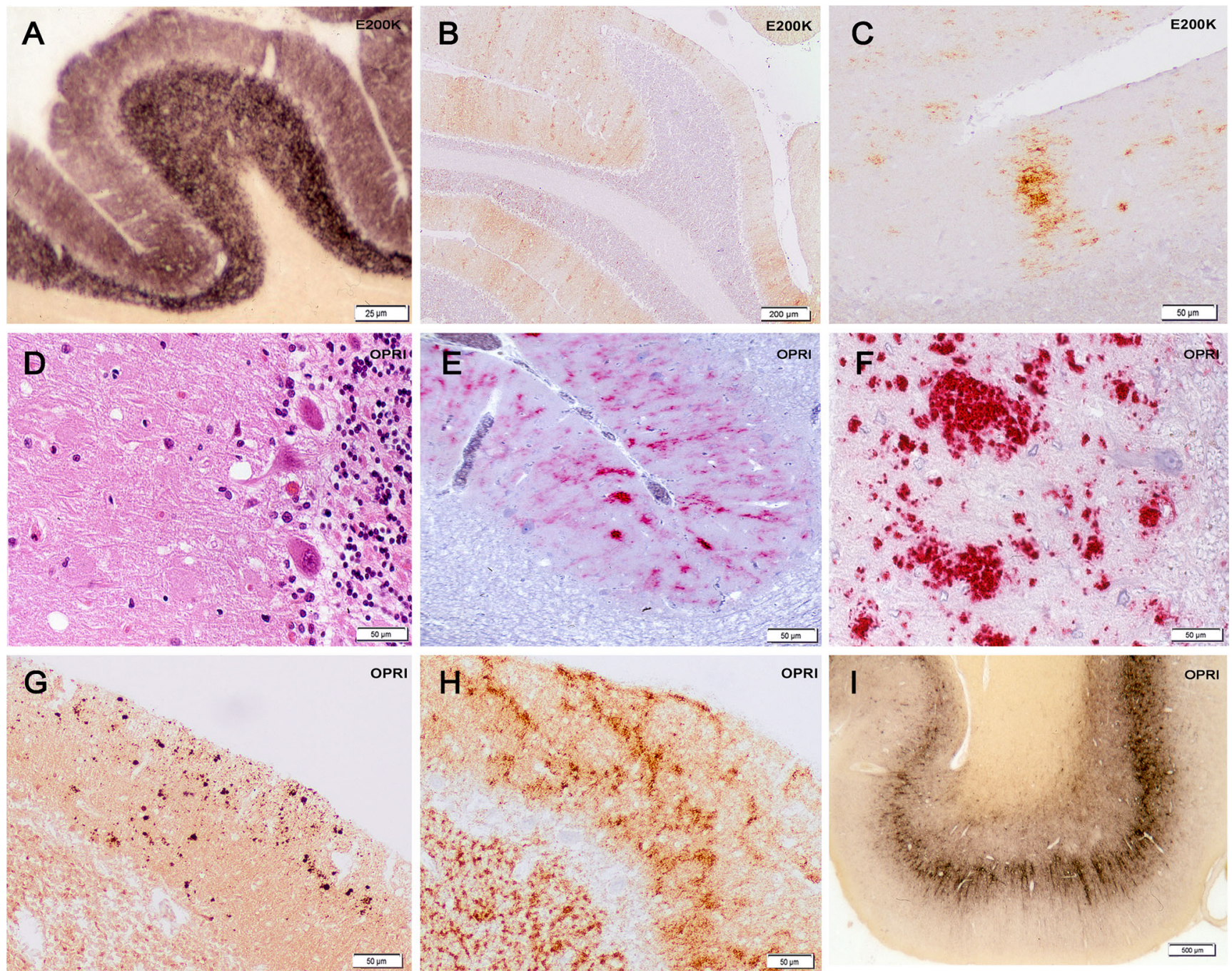

Fig. 1 Histopathological findings in fCJD (E200K. octa-peptide repeat insertion (OPRI)): In E200K patients, immunohistochemical detection of $\mathrm{PrP}^{\mathrm{Sc}}$ aggregates usually reveal pattern, indistinguishable from sporadic CJD cases (a). Some E200K cases may show stripe-like prion deposits in the molecular layer of the cerebellum $(\mathbf{b}, \mathbf{c})$. In octa-peptide repeat insertion patients, immunohistochemical detection of $\mathrm{PrP}^{\mathrm{Sc}}$ aggregates usually shows a patchy or tigroid pattern $(\mathbf{d}-\mathbf{h})$. Conventional anti-prion immunohistochemistry is depicted either in brown $(\mathbf{a}-\mathbf{c}, \mathbf{g}-\mathbf{i})$ or in red color (e, f) for visualization, performed according the protocol from [124, 125]. In paraffin-embedded tissue (PET) blots (a, i; [126]), prion aggregates are stained dark brown. H\&E staining in $\mathbf{g}$ corresponds to immunohistochemistry in $\mathbf{h}$. Magnification bars are indicated associated with axonal swelling in granule cell layer (torpedoes) (Fig. 2c).

Spongiform changes of the neuropil may be absent or only focally seen in the parahippocampal region (Fig. 2d). Abnormal $\mathrm{PrP}^{\mathrm{Sc}}$ deposits can be absent (Fig. 2e) or only focally seen in areas with spongiform changes (Fig. 2f).

Biochemical typing of FFI reveals the expression of $\operatorname{PrP}^{\mathrm{Sc}}$ type 2 (MW of unglycosylated $\operatorname{PrP}=19 \mathrm{kDa}$ ). The amount of $\mathrm{PrP}^{\mathrm{Sc}}$ in FFI is typically very low. Additionally, the resistance of $\mathrm{PrP}^{\mathrm{Sc}}$ to proteinase $\mathrm{K}(\mathrm{PK})$ is decreased which makes it difficult to detect the proteinaseresistant fragments by Western blot (Fig. 4c). Protein aggregate filtration techniques may overcome these diagnostic problems [124].
In contrast, carriers of the PRNP D178N mutation, which exhibit $P R N P$ codon $129 \mathrm{~V}$ at the same allele, are classified as fCJD cases. This patient group shows a more abundant PKresistant $\mathrm{PrP}^{\mathrm{Sc}}$ banding pattern (Fig. 4a). The $\mathrm{PrP}^{\mathrm{Sc}}$ isoform composition revealed an under-representation of the unglycosylated band at $21 \mathrm{kDa}\left(\mathrm{PrP}^{\mathrm{Sc}}\right.$ type 1$)$ and an enrichment of $\operatorname{PrP}^{\mathrm{Sc}}$ in certain brain regions, such as the parietal and frontal cortex compared to the occipital cortex, striatum, and cerebellum (Fig. 4a).

\section{PRNP Mutations Causing GSS}

GSS, originally described by Gerstmann et al. [137], has been associated with many different point mutations (e.g., 

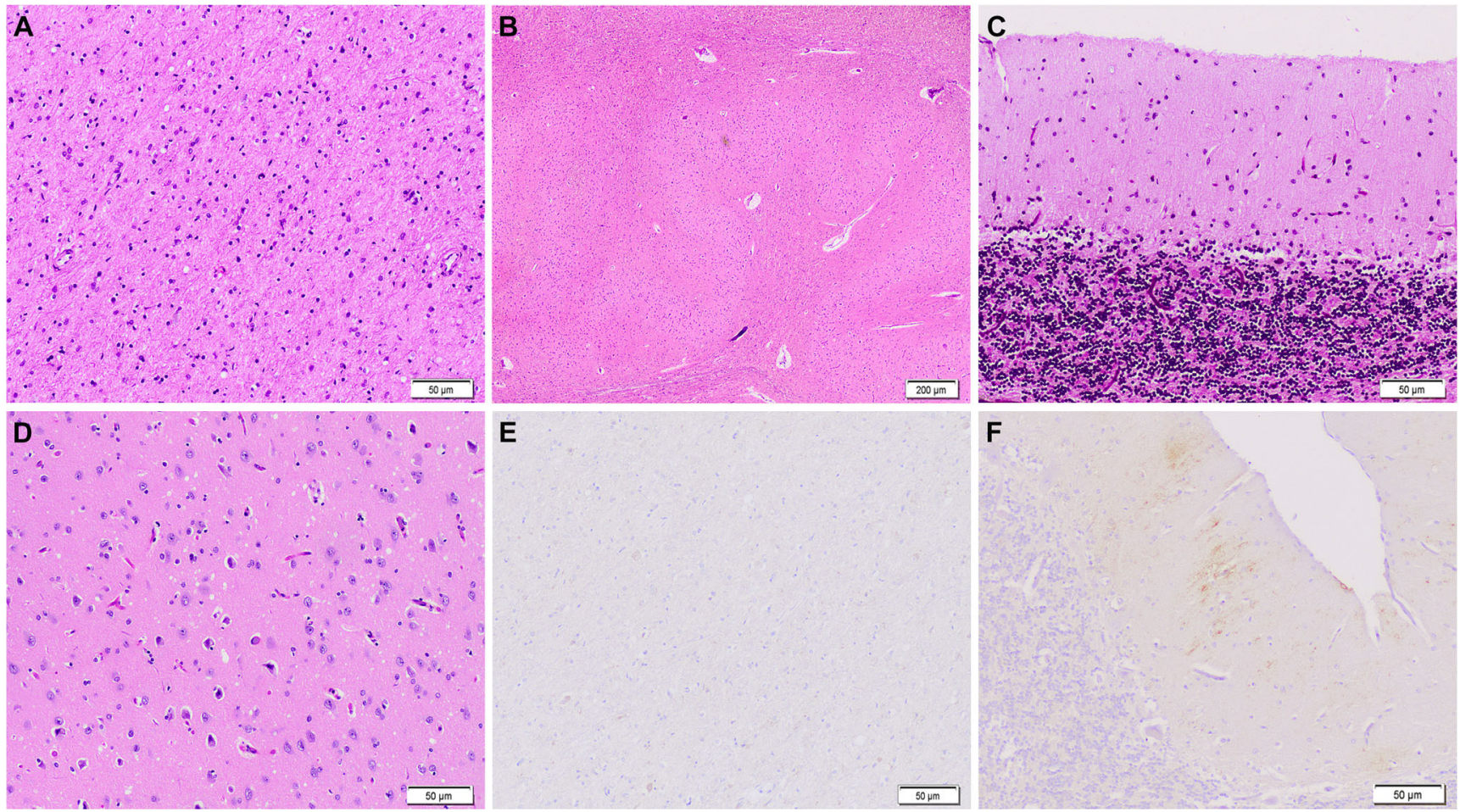

E

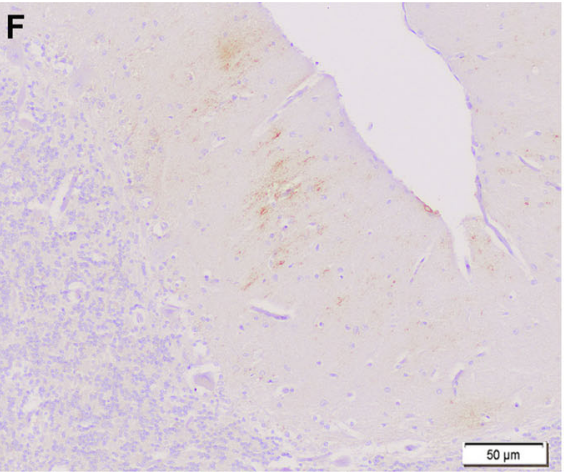

Fig. 2 Representative neuropathological features of FFI. Severe neuronal loss in thalamic nuclei associated with prominent astrogliosis and microglial activation (a). Similar changes can also be observed in the inferior olivary nucleus (b). In the cerebellum, extensive Purkinje cell loss can be detected (c) frequently associated with axonal swelling in the granule cell layer (torpedoes). Spongiform changes in molecular layer are hardly or only focally seen and may be detected in the parahippocampal region (d). Similarly, abnormal PrP deposits may be absent (e, thalamus) or only focally detectable in areas with spongiform alteration such as the subiculum or cerebellar molecular layer (f). a-d H\&E staining; e, f anti-prion immunohistochemistry [124, 125] mutations at codons 102, 105, 117, Y145 stop mutation etc. (Table 1) or insertional mutations of octa-peptide repeats (Table 2). The most common cause of GSS is a single base exchange at codon 102 which results in an amino acid residue change from proline to leucine (P102L). The onset of GSS occurs at an age between 40 and 60 years and the percentage of family history is $70 \%$ [9]. Clinically, GSS is associated with prominent ataxia. Dementia usually occurs at the late stage of the disease over a course of 1 to 7 years [15].

A characteristic feature of GSS is the appearance of large multicentric PrP-amyloid plaques, stained with hematoxylineosin, in the molecular layer of the cerebellum (Fig. 3a, b). Spongiform changes are fequently missing. In some GSS patients, the composite of the PrP plaques show a halo (Fig. 3a, d), but in others not (Fig. 3b, c, e, f).

Moreover, prominent neurofibrillary, tau-positive pathology has been observed in patients exhibiting a PRNP mutation at codon 105, 145, and 217 [42, 138, 139].

In Western blot, GSS patients and carriers of the PRNP P102L mutation typically show an additional proteinase K-resistant protein fragment of 7 to $10 \mathrm{kDa}$ of molecular size. A proteinase K-resistant ladder-like $\mathrm{PrP}^{\mathrm{Sc}}$ banding pattern may also occur in GSS patients (Fig. 4d).

\section{PRNP Mutations with an Unknown Significance}

Phenotypes of different $P R N P$ mutations may be variable. The majority of $P R N P$ mutations are related to a prion or a prionlike disease. However, certain PRNP mutations have also been described in non-prion disease patients. For example, the octarepeat deletion around codon 82 with a familiar history is linked to phenotype which is similar to Alzheimer's disease [140]. Another report described a family with a 288 base pair insertion consisting of 12 octa-peptide repeats which exhibited the clinical behavior changes and neuroimaging features of atypical frontotemporal dementia (FTD) cases [123]. Moreover, a recent report has even identified a PRNP variant, the G127V, which completely prevents prion disease as shown in mice but not yet in humans [35]. 
Fig. 3 Typical neuropathological features of GSS. a, $\mathbf{b}$ GSS plaques can be observed in the molecular layer of the cerebellum detectable by conventional hematoxylineosin staining. Spongiform changes are absent.

Immunohistochemical anti-prion reactions show abundant multicentric plaques. In some cases, composite plaques show a halo $(\mathbf{a}, \mathbf{d})$, but in others not $(\mathbf{b}, \mathbf{c}$, e, f). c, $\mathbf{d}$ prion PET blot; prion aggregates in dark brown; $\mathbf{e , f}$ conventional anti-prion immunohistochemical staining revealed abundant pathological $\mathrm{PrP}^{\mathrm{Sc}}$ deposits in gray matter (brown color reaction)

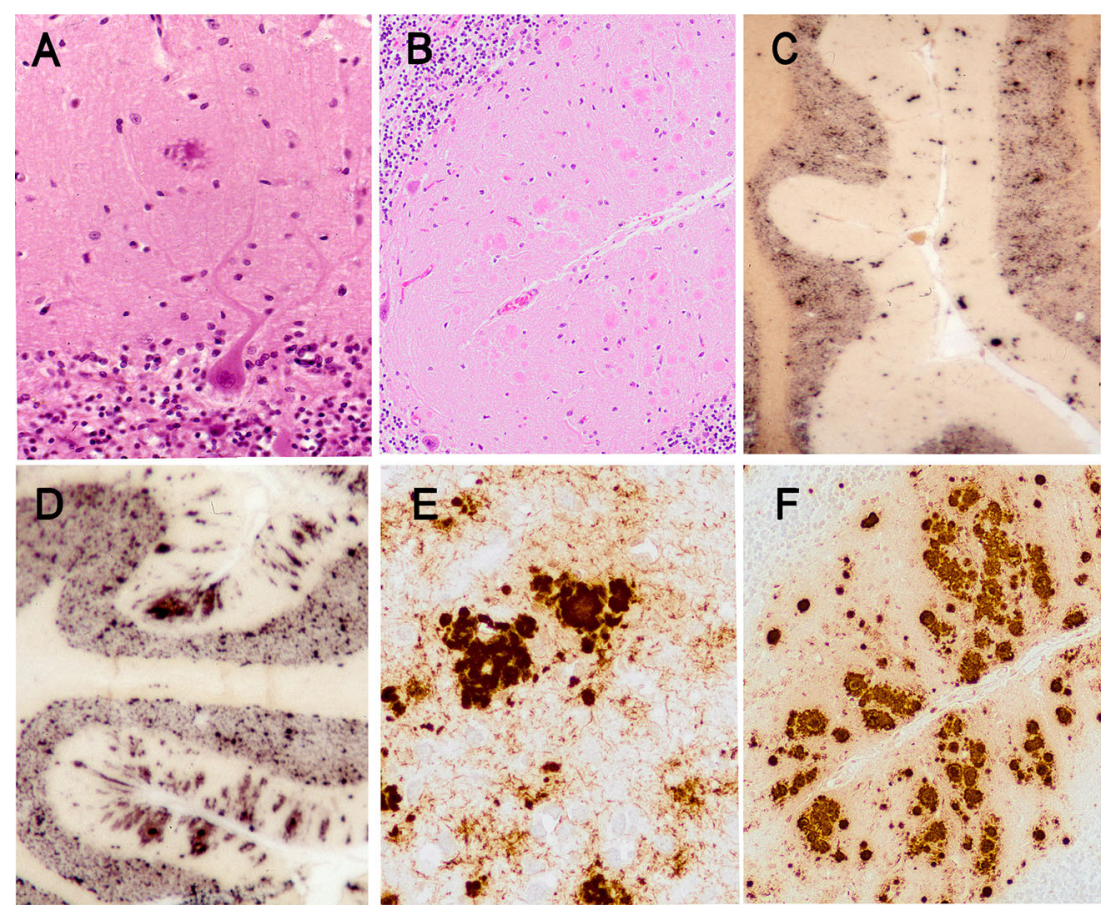

A

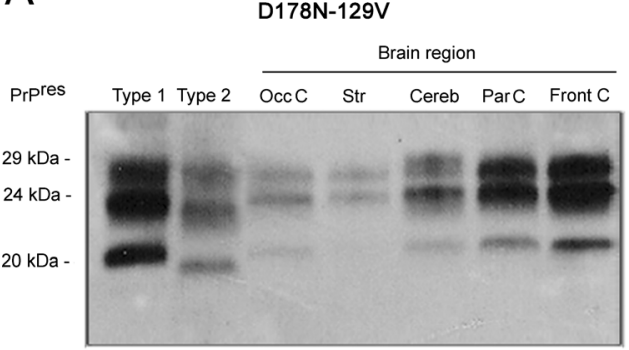

C Prpres D178N-129M: FFI

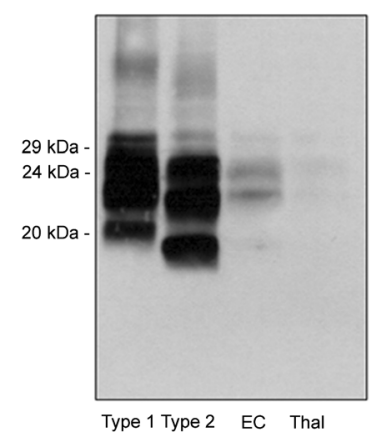

Fig. 4 Detection of PK-resistant $\mathrm{PrP}^{\mathrm{Sc}}$ isoform profiles by Western blot in gCJD cases. a Analysis of $\mathrm{PrP}^{\mathrm{Sc}}$ isoforms in different brain regions of an fCJD patient carrying the D178N-129 V mutation. The banding pattern of the D178N-129 V patient revealed an under-representation of the unglycosylated band at $21 \mathrm{kDa}$ (prion type 1). b Western blot analysis (described previously [124, 125] of $\mathrm{PrP}^{\mathrm{Sc}}$ profiles from the frontal cortex of different fCJD patients are classified according to their PrP type. E200K $129 \mathrm{M}$-, 4-OPRI $129 \mathrm{M}$-, and V210I $129 \mathrm{M}$ carriers express $\mathrm{PrP}^{\mathrm{Sc}}$ type 1 (unglycosylated PrP form: $21 \mathrm{kDa}$ ), while E200K 129 V, 4-OPRI $129 \mathrm{~V}$,

B

D

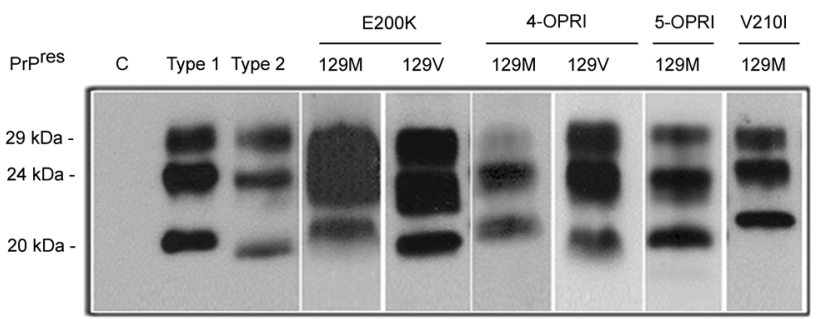
Prpres P102L-129V: GSS

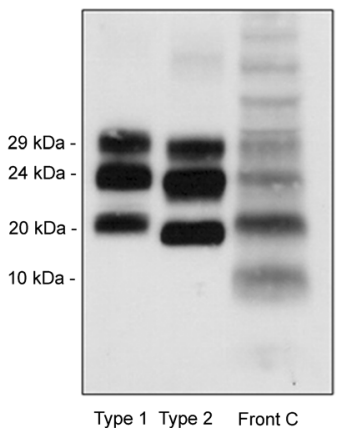

and 5-OPRI $129 \mathrm{M}$ carriers exhibit $\mathrm{PrP}^{\mathrm{Sc}}$ type 2 (unglycosylated PrP form: $19 \mathrm{kDa}$ ). In $\mathbf{c}$, the $\mathrm{PrP}^{\mathrm{Sc}}$ profile of an FFI patient, and in $\mathbf{d}$, the $\operatorname{PrP}^{\mathrm{Sc}}$ profile of a GSS patient is shown. While $\mathrm{PrP}^{\mathrm{Sc}}$ in the FFI patient is less $\mathrm{PK}$ resistant with a low representation of the unglycosylated PrP band, the GSS mutation may cause the expression of a characteristic 7-10 $\mathrm{kDa} \operatorname{PrP}^{\mathrm{Sc}}$ fragment. Abbreviations: $C$ control, $O c c C$ occipital cortex, Str striatum, Cereb cerebellum, $\operatorname{Par} C$ parietal cortex, Front $C$ frontal cortex, EC entorhinal cortex, Thal thalamus 


\section{Conclusion}

To date, more than 50 different mutations in PRNP that may result in diverse clinicopathological phenotypes have been documented. Some genetic cases (GSS) even show a co-pathology of $\mathrm{PrP}^{\mathrm{Sc}}$ and amyloid beta plaques or neurofibrillary tangles. STOP mutations in the PRNP cause quite characteristic banding patterns of PK-resistant $\mathrm{PrP}^{\mathrm{Sc}}$ in brain tissue. Since several $P R N P$ mutations show a disease course resembling classical SCJD and appear to occur spontaneously with no family history and with a variable penetrance, they may remain undiscovered.

\section{References}

1. Imran M, Mahmood S (2011) An overview of human prion diseases. Virol J 8:559

2. Cramm M, Schmitz M, Zafar S, Karch A, Mitrova E, Schroeder B, Raeber A, Kuhn F, Satoh K, Collins S, Zerr I (2016) Stability and Reproducibility Underscore Utility of RT-QuIC for Diagnosis of Creutzfeldt-Jakob Disease. Mol Neurobiol 53:1896-1904

3. Krasnianski A, Bartl M, Sanchez-Juan PJ, Heinemann U, Meissner B, Varges D et al (2008) Fatal familial insomnia: clinical features and early identification. Ann Neurol 63:658-661

4. WHO. (1998) Human transmissible spongiform encephalopathies. Wkly Epidemiol Rec 47:361-5

5. Gambetti P, Kong Q, Zou W, Parchi P, Chen S (2003) Sporadic and familial CJD: classification and characterisation. Br Med Bull 66:213-239

6. Mastrianni JA (2010) The genetics of prion diseases. Genet Med 12:187-195

7. Spudich S, Mastrianni JA, Wrensch M, Gabizon R, Meiner Z, Kahana I et al (1995) Complete penetrance of Creutzfeldt-Jakob disease in Libyan Jews carrying the E200K mutation in the prion protein gene. Mol Med 1:607-613

8. Kobayashi A, Teruya K, Matsuura Y, Shirai T, Nakamura Y, Yamada $\mathrm{M}$ et al (2015) The influence of PRNP polymorphisms on human prion disease susceptibility: an update. Acta Neuropathol 130:159-170

9. Kovács GG, Puopolo M, Ladogana A, Pocchiari M, Budka H, van Duijn C et al (2005) Genetic prion disease: the EUROCJD experience. Hum Genet 118:166-174

10. Parchi P, Giese A, Capellari S, et al (1999) Classification of sporadic Creutzfeldt-Jakob disease based on molecular and phenotypic analysis of 300 subjects. Ann Neurol 46:224-233

11. Puoti G, Rossi G, Giaccone G, Awan T, Lievens PM, Defanti CA et al (2000) Polymorphism at codon 129 of PRNP affects the phenotypic expression of Creutzfeldt-Jakob disease linked to E200K mutation. Ann Neurol 48:269-270

12. Kaski DN, Pennington C, Beck J, Poulter M,Uphill J, Bishop MT, Linehan JM et al. (2011) Inherited prion disease with 4-octapeptide repeat insertion: disease requires the interaction of multiple genetic risk factors. Brain 134:1829-1838

13. Capellari S, Strammiello R, Saverioni D, Kretzschmar H, Parchi P (2011) Genetic Creutzfeldt-Jakob disease and fatal familial insomnia: insights into phenotypic variability and disease pathogenesis. Acta Neuropathol 121:21-37

14. Liao YC, Lebo RV, Clawson GA, Smuckler EA (1986) Human prion protein cDNA: molecular cloning, chromosomal mapping, and biological implications. Science 233:364-367
15. Brown K, Mastrianni J (2010) The prion diseases. J Geriatr Psychiatry Neurol 23:277-298

16. Jeong BH, Kim YS (2014) Genetic studies in human prion diseases. J Korean Med Sci 29:623-632

17. Goldfarb LG, Brown P, McCombie WR, Goldgaber D, Swergold GD, Wills PR et al (1991) Transmissible familial CreutzfeldtJakob disease associated with five, seven, and eight extra octapeptide coding repeats in the PRNP gene. Proc Natl Acad Sci U S A 88:10926-10930

18. Jansen C, Parchi P, Capellari S, Vermeij AJ, Corrado P, Baas F et al (2010) Prion protein amyloidosis with divergent phenotype associated with two novel nonsense mutations in PRNP. Acta Neuropathol 119:189-197

19. Windl O, Giese A, Schulz-Schaeffer W, Zerr I, Skworc K, Arendt $S$ et al (1999) Molecular genetics of human prion diseases in Germany. Hum Genet 105:244-252

20. Bernardi L, Cupidi C, Frangipane F, Anfossi M, Gallo M, Conidi ME et al (2014) Novel N-terminal domain mutation in prion protein detected in 2 patients diagnosed with frontotemporal lobar degeneration syndrome. Neurobiol Aging 35:2657.e7-2657.e11

21. Oldoni E, Fumagalli GG, Serpente M, Fenoglio C, Scarioni M, Arighi A et al. (2016) PRNP P39L Variant is a Rare Cause of Frontotemporal Dementia in Italian Population. J Alzheimers Dis. 50:353-357

22. Schelzke G, Stoeck K, Eigenbrod S, Grasbon-Frodl E, Raddaz LM, Ponto C et al (2013) Report about four novel mutations in the prion protein gene. Dement Geriatr Cogn Disord 35:229-237

23. Beck JA, Poulter M, Campbell TA, Adamson G, Uphill JB, Guerreiro R et al (2010) PRNP allelic series from 19 years of prion protein gene sequencing at the MRC Prion Unit. Hum Mutat 31: E1551-E1563

24. Jones M, Odunsi S, du Plessis D, Vincent A, Bishop M, Head MW et al (2014) Gerstmann-Sträussler-Scheinker disease: novel PRNP mutation and VGKC-complex antibodies. Neurology 82:2107-2111

25. Zheng L, Longfei J, Jing Y, Xinqing Z, Haiqing S, Haiyan L et al (2008) PRNP mutations in a series of apparently sporadic neurodegenerative dementias in China. Am J Med Genet B Neuropsychiatr Genet 147:938-944

26. Hsiao K, Baker HF, Crow TJ, Poulter M, Owen F, Terwilliger JD et al (1989) Linkage of a prion protein missense variant to Gerstmann-Sträussler syndrome. Nature 338:342-345

27. Iwasaki Y, Mori K, Ito M, Nokura K, Tatsumi S, Mimuro M et al (2014) Gerstmann-Sträussler-Scheinker disease with P102L prion protein gene mutation presenting with rapidly progressive clinical course. Clin Neuropathol 33:344-353

28. Kitamoto T, Amano N, Terao Y, Nakazato Y, Isshiki T, Mizutani T et al (1993) A new inherited prion disease (PrP-P105L mutation) showing spastic paraparesis. Ann Neurol 34:808-813

29. Rogaeva E, Zadikoff C, Ponesse J, Schmitt-Ulms G, Kawarai T, Sato C et al (2006) Childhood onset in familial prion disease with a novel mutation in the PRNP gene. Arch Neurol 63:1016-1021

30. Tunnell E, Wollman R, Mallik S, Cortes CJ, Dearmond SJ, Mastrianni JA (2008) A novel PRNP-P105S mutation associated with atypical prion disease and a rare $\mathrm{PrP}^{\mathrm{Sc}}$ conformation. Neurology 71:1431-1438

31. Rodriguez MM, Peoc'h K, Haïk S, Bouchet C, Vernengo L, Mañana $\mathrm{H}$ et al (2005) A novel mutation (G114V) in the prion protein gene in a family with inherited prion disease. Neurology 64:1455-1457

32. Doh-ura K, Tateishi J, Kitamoto T, Sasaki H, Sakaki Y (1990) Creutzfeldt-Jakob disease patients with congophilic kuru plaques have the missense variant prion protein common to GerstmannSträussler-Scheinker syndrome. Ann Neurol 27:121-126

33. Hsiao KK, Cass C, Schellenberg GD, Bird T, Devine GE, Wisniewski $\mathrm{H}$ et al (1991) A prion protein variant in a family with the telencephalic form of Gerstmann-Sträussler-Scheinker syndrome. Neurology 41:681-684 
34. Mead S, Whitfield J, Poulter M, Shah P, Uphill J, Campbell T et al (2009) A novel protective prion protein variant that colocalizes with kuru exposure. N Engl J Med 361:2056-2065

35. Asante EA, Smidak M, Grimshaw A, Houghton R, Tomlinson A, Jeelani A et al (2015) A naturally occurring variant of the human prion protein completely prevents prion disease. Nature 522:478481

36. Zhou S, Shi D, Liu X, Liu H, Yao X (2016) Protective V127 prion variant prevents prion disease by interrupting the formation of dimer and fibril from molecular dynamics simulations. Sci Rep 6:21804

37. Panegyres PK, Toufexis K, Kakulas BA, Cernevakova L, Brown P, Ghetti B et al (2001) A new PRNP mutation (G131V) associated with Gerstmann-Sträussler-Scheinker disease. Arch Neurol 58:1899-1902

38. Jansen C, Voet W, Head MW, Parchi P, Yull H, Verrips A et al (2011) A novel seven-octapeptide repeat insertion in the prion protein gene (PRNP) in a Dutch pedigree with GerstmannSträussler-Scheinker disease phenotype: comparison with similar cases from the literature. Acta Neuropathol 121:59-68

39. Hilton DA, Head MW, Singh VK, Bishop M, Ironside JW (2009) Familial prion disease with a novel serine to isoleucine mutation at codon 132 or prion protein gene (PRNP). Neuropathol Appl Neurobiol 35:111-115

40. Rowe DB, Lewis V, Needham M, Rodriguez M, Boyd A, McLean $C$ et al (2007) Novel prion protein gene mutation presenting with subacute PSP-like syndrome. Neurology 68:868-870

41. Kitamoto T, Iizuka R, Tateishi J (1993) An amber mutation of prion protein in Gerstmann-Sträussler-Scheinker syndrome with mutant PrP plaques. Biochem Biophys Res Commun 192:525531

42. Ghetti B, Piccardo P, Spillantini MG, Ichimiya Y, Porro M, Perini F et al (1996) Vascular variant of prion protein cerebral amyloidosis with tau-positive neurofibrillary tangles: the phenotype of the stop codon 145 mutation in PRNP. Proc Natl Acad Sci U S A 93: 744-748

43. Pastore M, Chin SS, Bell KL, Dong Z, Yang Q, Yang L et al (2005) Creutzfeldt-Jakob disease (CJD) with a mutation at codon 148 of prion protein gene: relationship with sporadic CJD. Am J Pathol 167:1729-1738

44. Finckh U, Muller-Thomsen T, Mann U, Eggers C, Marksteiner J, Meins W et al (2000) High prevalence of pathogenic mutations in patients with early-onset dementia detected by sequence analyses of four different genes. Am J Hum Genet 66:110-117

45. Revesz T, Holton JL, Lashley T, Plant G, Frangione B, Rostagno A et al (2009) Genetics and molecular pathogenetics of sporadic and hereditary cerebral amyloid angiopathies. Acta Neuropathol 118:115-130

46. Mead S, Gandhi S, Beck J, Caine D, Gajulapalli D, Carswell C et al (2013) A novel prion disease associated with diarrhea and autonomic neuropathy. N Engl J Med 369:1904-1914

47. Themistocleous AC, Kennett R, Husain M, Palace J, Mead S, Bennett DL (2014) Late onset hereditary sensory and autonomic neuropathy with cognitive impairment associated with Y163X prion mutation. J Neurol 261:2230-2233

48. Samaia HB, Mari JJ, Vallada HP, Moura RP, Simpson AJ, Brentani RR (1997) A prion-linked psychiatric disorder [letter]. Nature 390:241

49. Simpson M, Johannsen V, Boyd A, Klug G, Masters CL, Li QX et al (2013) Unusual clinical and molecular-pathological profile of Gerstmann-Sträussler-Scheinker disease associated with a novel PRNP mutation (V176G). JAMA Neurol 70:1180-1185

50. Gambetti P, Parchi P, Petersen RB, Chen SG, Lugaresi E (1995) Fatal familial insomnia and familial Creutzfeldt-Jakob disease: clinical, pathological and molecular features. Brain Pathol 5:43-51
51. Kretzschmar HA, Neumann M, Stavrou D. (1995) Codon 178 mutation of the human prion protein gene in a German family (Backer family): sequencing data from 72-year-old celloidin-embedded brain tissue. Acta Neuropathol 89:96-98

52. Goldfarb LG, Petersen RB, Tabaton M, Brown P, LeBlanc AC, Montagna $\mathrm{P}$ et al (1992) Fatal familial insomnia and familial Creutzfeldt-Jakob disease: disease phenotype determined by a DNA polymorphism. Science 258:806-808

53. Kitamoto T, Ohta M, Doh-ura K, Hitoshi S, Terao Y, Tateishi J (1993) Novel missense variants of prion protein in CreutzfeldtJakob disease or Gerstmann-Sträussler syndrome. Biochem Biophys Res Commun 191:709-714

54. Amano Y, Kimura N, Hanaoka T, Aso Y, Hirano T, Murai H et al (2015) Creutzfeldt-Jakob Disease with a prion protein gene codon 180 mutation presenting asymmetric cortical high-intensity on magnetic resonance imaging. Prion 9:29-33

55. Nitrini R, Rosemberg S, Passos-Bueno MR, da Silva LS, Iughetti P, Papadopoulos M et al (1997) Familial spongiform encephalopathy associated with a novel prion protein gene mutation. Ann Neurol 42:138-146

56. Hall DA, Leehey MA, Filley CM, Steinbart E, Montine T, Schellenberg GD et al (2005) PRNP H187R mutation associated with neuropsychiatric disorders in childhood and dementia. Neurology 64:1304-1306

57. Colucci M, Moleres FJ, Xie ZL, Ray-Chaudhury A, Gutti S, Butefisch CM et al (2006) Gerstmann-Sträussler-Scheinker: a new phenotype with "curly" PrP deposits. J Neuropathol Exp Neurol 65:642-651

58. Chen C, Shi Q, Zhou W, Zhang XC, Dong JH, Hu XQ et al (2013) Clinical and familial characteristics of eight Chinese patients with T188K genetic Creutzfeldt-Jakob disease. Infect Genet Evol 14: $120-124$

59. Collins S, Boyd A, Fletcher A, Byron K, Harper C, McLean CA et al (2000) Novel prion protein gene mutation in an octogenarian with Creutzfeldt-Jakob disease. Arch Neurol 57:1058-1063

60. Roeber S, Grasbon-Frodl EM, Windl O, Krebs B, Xiang W, Vollmert C et al (2008) Evidence for a pathogenic role of different mutations at codon 188 or PRNP. PLoS One 3, e2147

61. Kotta K, Paspaltsis I, Bostantjopoulou S, Latsoudis H, Plaitakis A, Kazis D et al (2006) Novel mutation of the PRNP gene of a clinical CJD case. BMC Infect Dis 6:169

62. Peoc'h K, Manivet P, Beaudry P, Attane F, Besson G, Hannequin $D$ et al (2000) Identification of three novel mutations (E196K, V203I, E211Q) in the prion protein gene (PRNP) in inherited prion diseases with Creutzfeldt-Jakob disease phenotype. Hum Mutat 15:482

63. Zhang H, Wang M, Wu L, Zhang H, Jin T, Wu J et al (2014) Novel prion protein gene mutation at codon 196 (E196A) in a septuagenarian with Creutzfeldt-Jakob disease. J Clin Neurosci 21:175-178

64. Uflacker A, Doraiswamy PM, Rechitsky S, See T, Geschwind M, Tur-Kaspa I (2014) Preimplantation genetic diagnosis (PGD) for genetic prion disorder due to F198S mutation in the PRNP gene. JAMA Neurol 71:484-486

65. Unverzagt FW, Farlow MR, Norton J, Dlouhy SR, Young K, Ghetti B (1997) Neuropsychological function in patients with Gerstmann-Sträussler-Scheinker disease from the Indiana kindred (F198S). J Int Neuropsychol Soc 3:169-178

66. Goldfarb LG, Korczyn AD, Brown P, Chapman J, Gadjusek DC (1990) Mutation in codon 200 of scrapie amyloid precursor gene linked to Creutzfeldt-Jakob disease in Sephardic Jews of Libyan and non-Libyan origin. Lancet 336:637-638

67. Kim MO, Cali I, Oehler A, Fong JC, Wong K, See T et al (2013) Genetic CJD with a novel E200G mutation in the prion protein gene and comparison with E200K mutation cases. Acta Neuropathol Commun 1:80 
68. Piccardo P, Dlouhy SR, Lievens PM, Young K, Bird TD, Nochlin D et al (1998) Phenotypic variability of Gerstmann-SträusslerScheinker disease is associated with prion protein heterogeneity. J Neuropathol Exp Neurol 57:979-988

69. Heinemann U, Krasnianski A, Meissner B, Grasbon-Frodl EM, Kretzschmar HA, Zerr I (2008) Novel PRNP mutation in a patient with a slow progressive dementia syndrome. Med Sci Monit 14: $41-43$

70. Shi Q, Chen C, Wang XJ, Zhou W, Wang JC, Zhang BY et al (2013) Rare V203I mutation in the PRNP gene of a Chinese patient with Creutzfeldt-Jakob disease. Prion 7:259-262

71. Mastrianni JA, Iannicola C, Myers RM, DeArmond S, Prusiner SB (1996) Mutation of the prion protein gene at codon 208 in familial Creutzfeldt-Jakob disease. Neurology 47:1305-1312

72. Basset-Leobon C, Uro-Coste E, Peoc'h K, Haik S, Sazdovitch V, Rigal $M$ et al (2006) Familial Creutzfeldt-Jakob disease with an R208H-129V haplotype and Kuru plaques. Arch Neurol 63:449452

73. Pocchiari M, Salvatore M, Cutruzzola F, Genuardi M, Allocatelli CT, Masullo C et al (1993) A new point mutation of the prion protein gene in Creutzfeldt-Jakob disease. Ann Neurol 34:802807

74. Imbriani P, Marfia GA, Marciani MG, Poleggi A, Pocchiari M, Puoti G et al (2015) Heidenhain variant in two patients with inherited V210I Creutzfeldt-Jakob disease. Int J Neurosci 126: 381-383

75. Ladogana A, Almonti S, Petraroli R, Giaccaglini E, Ciarmatori C, Liu QG et al (2001) Mutation of the PRNP gene at codon 211 in familial Creutzfeldt-Jakob disease. Am J Med Genet 103:133-137

76. Peoc'h K, Levavasseur E, Delmont E, De Simone A, LaffontProust I, Privat N et al (2012) Substitutions at residue 211 in the prion protein drive a switch between CJD and GSS syndrome, a new mechanism governing inherited neurodegenerative disorders. Hum Mol Genet 21:5417-5428

77. Muñoz-Nieto M, Ramonet N, López-Gastón JI, CuadradoCorrales N, Calero O, Díaz-Hurtado M, Ipiens JR, Ramón y Cajal S, de Pedro-Cuesta J, Calero M (2013) A novel mutation I215V in the PRNP gene associated with Creutzfeldt-Jakob and Alzheimer's diseases in three patients with divergent clinical phenotypes. J Neurol 260:77-84

78. Hsiao K, Dlouhy SR, Farlow MR, Cass C, Da Costa M, Conneally PM et al (1992) Mutant prion proteins in Gerstmann-SträusslerScheinker disease with neurofibrillary tangles. Nat Genet 1:68-71

79. Alzualde A, Indakoetxea B, Ferrer I, Moreno F, Barandiaran M, Gorostidi A et al (2010) A novel PRNP Y218N mutation in Gerstmann-Sträussler-Scheinker disease with neurofibrillary degeneration. J Neuropathol Exp Neurol 69:789-800

80. Furukawa H, Kitamoto T, Tanaka Y, Tateishi J (1995) New variant prion protein in a Japanese family with Gerstmann-SträusslerScheinker syndrome. Brain Res Mol Brain Res 30:385-388

81. Tanaka Y, Minematsu K, Moriyasu H, Yamaguchi T, Yutani C, Kitamoto T et al (1997) A Japanese family with a variant of Gerstmann-Sträussler-Scheinker disease. J Neurol Neurosurg Psychiatry 62:454-457

82. Hoque MZ, Kitamoto T, Furukawa H, Muramoto T, Tateishi J (1996) Mutation in the prion protein gene at codon 232 in Japanese patients with Creutzfeldt-Jakob disease: a clinicopathological, immunohistochemical and transmission study. Acta Neuropathol 92:441-446

83. Choi BY, Kim SY, Seo SY, An SS, Kim S, Park SE et al (2009) Mutations at codons $178,200-129$, and 232 contributed to the inherited prion diseases in Korean patients. BMC Infect Dis 9:132

84. Kon T, Miki Y, Arai A, Funamizu Y, Ueno T, Haga R et al (2015) Creutzfeldt-Jakob disease with homozygous M232R mutation: a case report. J Neurol Sci 352:108-109
85. Palmer MS, Mahal SP, Campbell TA, Hill AF, Sidle KC, Laplanche JL et al (1993) Deletions in the prion protein gene are not associated with CJD. Hum Mol Genet 2:541-544

86. Laplanche JL, Delasnerie-Lauprli R, Giaccagli JP, Dussaucy M, Chatelain J, Launay JM (1995) Two novel insertions in the prion protein gene in patients with late-onset dementia. Hum Mol Genet 4:1109-1111

87. Goldfarb LG, Brown P, Little BW, Cervenakova L, Kenney K, Gibbs CJ et al (1993) A new (two-repeat) octapeptide coding insert mutation in Creutzfeldt-Jakob disease. Neurology 43: 2392-2394

88. van Harten B, van Gool WA, Van Langen IM, Deekman JM, Meijerink PH, Weinstein HC (2000) A new mutation in the prion protein gene: a patient with dementia and white matter changes. Neurology 55:1055-1057

89. Croes EA, Theuns J, Houwing-Duistermaat JJ, Dermaut B, Sleegers K, Roks G et al (2004) Octapeptide repeat insertions in the prion protein gene and early onset dementia. J Neurol Neurosurg Psychiatry 75:1166-1170

90. Grasbon-Frodl E, Schmalzbauer R, Weber P, Krebs B, Windl O, Zerr I et al (2004) A novel three extra-repeat insertion in the prion protein gene (PRNP) in a patient with Creutzfeldt-Jakob disease. Neurogenetics 5:249-250

91. Yu SL, Jin L, Sy MS, Mei FH, Kang SL, Sun GH et al (2004) Polymorphisms of the PRNP gene in Chinese populations and the identification of a novel insertion mutation. Eur J Hum Genet 12: 867-870

92. Nishida Y, Sodeyama N, Toru S, Kitamoto T, Mizusawa H (2004) Creutzfeldt-Jakob disease with a novel insertion and codon 219 Lys/Lys polymorphism in PRNP. Neurology 63:1978-1979

93. Rossi G, Giaccone G, Giampaolo L, Iussich S, Puoti G, Frigo M et al (2000) Creutzfeldt-Jakob disease with a novel four extra-repeat insertional mutation in the PrP gene. Neurology 55:405-410

94. Campbell TA, Palmer MS, Will RG, Gibb WR, Luthert PJ, Collinge J (1996) A prion disease with a novel 96-base pair insertional mutation in the prion protein gene. Neurology 46:761-766

95. Martinez-Saez E, Gelpi E, Rey MJ, Ferrer I, Ribalta T, Botta-Orfila T et al (2012) Hirano body-rich subtypes of Creutzfeldt-Jakob disease. Neuropathol Appl Neurobiol 38:153-161

96. Yanagihara C, Yasuda M, Maeda K, Miyoshi K, Nishimura Y (2002) Rapidly progressive dementia syndrome associated with a novel four extra repeat mutation in the prion protein gene. $\mathrm{J}$ Neurol Neurosurg Psychiatry 72:788-791

97. Cochran EJ, Bennett DA, Cervenakova L, Kenney K, Bernard B, Foster NL et al (1996) Familial Creutzfeldt-Jakob disease with a five-repeat octapeptide insert mutation. Neurology 47:727-733

98. Jansen C, van Swieten JC, Capellari S, Strammiello R, Parchi P, Rozemuller AJ (2009) Inherited Creutzfeldt-Jakob disease in a Dutch patient with a novel five octapeptide repeat insertion and unusual cerebellar morphology. J Neurol Neurosurg Psychiatry 80:1386-1389

99. Skworc KH, Windl O, Schulz-Schaeffer WJ, Giese A, Bergk J et al (1999) Familial Creutzfeldt-Jakob disease with a novel 120-bp insertion in the prion protein gene. Ann Neurol 46:693-700

100. Mead S, Webb TE, Campbell TA, Beck J, Linehan JM, Rutherfoord S et al (2007) Inherited prion disease with 5-OPRI: phenotype modification by repeat length and codon 129 . Neurology 69:730-738

101. Poulter M, Baker HF, Frith CD, Leach M, Lofthouse R, Ridley RM et al (1992) Inherited prion disease with 144 base pair gene insertion. 1. Genealogical and molecular studies. Brain 15:675685

102. Gelpi E, Kovacs GG, Ströbel T, Koperek O, Voigtländer T, Liberski PP et al (2005) Prion disease with a 144 base pair insertion: unusual cerebellar prion protein immunoreactivity. Acta Neuropathol 110:513-519 
103. Owen F, Poulter M, Lofthouse R, Collinge J, Crow TJ, Risby D et al (1989) Insertion in prion protein gene in familial CreutzfeldtJakob disease. Lancet 1:51-52

104. Oda T, Kitamoto T, Tateishi J, Mitsuhashi T, Iwabuchi K, Haga C et al (1995) Prion disease with 144 base pair insertion in a Japanese family line. Acta Neuropathol Berl 90:80-86

105. Nicholl D, Windl O, de Silva R, Sawcer S, Dempster M, Ironside JW et al (1995) Inherited Creutzfeldt-Jakob disease in a British family associated with a novel 144 base pair insertion of the prion protein gene. J Neurol Neurosurg Psychiatry 58:65-69

106. Capellari S, Vital C, Parchi P, Petersen RB, Ferrer X, Jarnier D et al (1997) Familial prion disease with a novel 144-bp insertion in the prion protein gene in a Basque family. Neurology 49:133-141

107. Vital A, Laplanche JL, Bastard JR, Xiao X, Zou WQ, Vital C (2011) A case of Gerstmann-Sträussler-Scheinker disease with a novel six octapeptide repeat insertion. Neuropathol Appl Neurobiol 37:554-559

108. Pietrini V, Puoti G, Limido L, Rossi G, Di Fede G, Giaccone G et al (2003) Creutzfeldt-Jakob disease with a novel extra-repeat insertional mutation in the PRNP gene. Neurology 61:1288-1291

109. Brown P, Goldfarb LG, McCombie WR, Nieto A, Squillacote D, Sheremata W et al (1992) Atypical Creutzfeldt-Jakob disease in an American family with an insert mutation in the PRNP amyloid precursor gene. Neurology 42:422-427

110. Wang XF, Guo YJ, Zhang BY, Zhao WQ, Gao JM, Wan YZ et al (2009) Creutzfeldt-Jakob disease in a Chinese patient with a novel seven extra-repeat insertion in PRNP. BMJ Case Rep 78:201-203

111. Cannella M, Martino T, Simonelli M, Ciammola A, Gradini R, Ciarmiello A et al (2009) De novo seven extra repeat expanded mutation in the PRNP gene in an Italian patient with early onset dementia. BMJ Case Rep 2009:bcr08.2008.0711

112. Mauro C, Giaccone G, Piscosquito G, Lavorgna A, Nigro M, Di Fede $\mathrm{G}$ et al (2008) A novel insertional mutation in the prion protein gene: clinical and bio-molecular findings. J Neurol Neurosurg Psychiatry 79:1395-1398

113. Tateishi J (1991) Recent advances in the research of CreutzfeldtJakob disease (CJD) and Gerstmann-Sträussler-Scheinker syndrome (GSS). Rinsho Shinkeigaku 31:1306-1308

114. Lewis V, Collins S, Hill AF, Boyd A, McLean CA, Smith MA et al (2003) Novel prion protein insert mutation associated with prolonged neurodegenerative illness. Neurology 60:1620-1624

115. Goldfarb LG, Brown P, Vrbovska A, Baron H, McCombie WR, Cathala F et al (1992) An insert mutation in the chromosome 20 amyloid precursor gene in a Gerstmann-Sträussler-Scheinker family. J Neurol Sci 111:189-194

116. van Gool WA, Hensels GW, Hoogerwaard EM, Wiezer JH, Wesseling P, Bolhuis PA (1995) Hypokinesia and presenile dementia in a Dutch family with a novel insertion in the prion protein gene. Brain 118:1565-1571

117. Laplanche JL, Hachimi KH, Durieux I, Thuillet P, Defebvre L, Delasnerie-Lauprêtre N et al (1999) Prominent psychiatric features and early onset in an inherited prion disease with a new insertional mutation in the prion protein gene. Brain 122:2375-2386

118. Moore RC, Xiang F, Monaghan J, Han D, Zhang Z, Edstrom L et al (2001) Huntington disease phenocopy is a familial prion disease. Am J Hum Genet 69:1385-1388

119. Duchen LW, Poulter M, Harding AE (1993) Dementia associated with a 216 base pair insertion in the prion protein gene. Clinical and neuropathological features. Brain 116:555-567

120. Krasemann S, Zerr I, Weber T, Poser S, Kretzschmar HA, Hunsmann $G$ et al (1995) Prion disease associated with a novel nine octapeptide repeat insertion in the PRNP gene. Mol Brain Res 34:173-176

121. Owen F, Poulter M, Collinge J, Leach M, Lofthouse R, Crow TJ et al (1992) A dementing illness associated with a novel insertion in the prion protein gene. Brain Res Mol Brain Res 13:155-157
122. Sánchez-Valle R, Aróstegui JI, Yagüe J, Rami L, Lladó A, Molinuevo JL (2008) First demonstrated de novo insertion in the prion protein gene in a young patient with dementia. $\mathrm{J}$ Neurol Neurosurg Psychiatry 79:845-846

123. Kumar N, Boeve BF, Boot BP, Orr CF, Duffy J, Woodruff BK et al (2011) Clinical characterization of a kindred with a novel 12octapeptide repeat insertion in the prion protein gene. Arch Neurol 68:1165-1170

124. Wemheuer WE, Wrede A, Gawinecka J, Zerr I, Schulz-Schaeffer W (2013) Filtration of protein aggregates increases the accuracy for diagnosing prion diseases in brain biopsies. J Neuropathol Exp Neurol 72:758-767

125. Wemheuer WM, Benestad SL, Wrede A, Schulze-Sturm U, Wemheuer WE, Hahmann U et al (2009) Similarities between forms of sheep scrapie and Creutzfeldt-Jakob disease are encoded by distinct prion types. Am J Pathol 175:2566-2573

126. Schulz-Schaeffer WJ, Tschöke S, Kranefuss N, Dröse W, HauseReitner D, Giese A, Groschup MH, Kretzschmar HA (2000) The paraffin-embedded tissue blot detects $\operatorname{PrP}(\mathrm{Sc})$ early in the incubation time in prion diseases. Am J Pathol 156:51-556

127. Jarius C, Kovacs GG, Head MW, Parchi P, Yull JA, Mitrova E, Budka H (2003) Distinctive cerebellar immunoreactivity for the prion protein in familial (E200K) Creutzfeldt-Jakob disease. Acta Neuropathol 105:449-454

128. Jayadev S, Nochlin D, Poorkaj P, Steinbart EJ, Mastrianni JA, Montine TJ et al (2011) Familial prion disease with Alzheimer disease-like tau pathology and clinical phenotype. Ann Neurol 69:712-720

129. Collinge J, Owen F, Poulter M, Leach M, Crow TJ, Rossor MN et al (1990) Prion dementia without characteristic pathology [see comments]. Lancet 336:7-9

130. Young K, Piccardo P, Dlouhy S, Bugiani O, Tagliavini F, Ghetti B (1999) The human genetic prion diseases. In: Harris DA (ed) Prions: molecular and cellular biology. Horizon Scientific Press, Wymondham, pp 139-175

131. Lugaresi E, Medori R, Montagna P, Baruzzi A, Cortelli P, Lugaresi A et al (1986) Fatal familial insomnia and dysautonomia with selective degeneration of thalamic nuclei. N Engl J Med 315:997-1003

132. Montagna P, Gambetti P, Cortelli P, Lugaresi E (2003) Familial and sporadic fatal insomnia. Lancet 2:167-176

133. Gambetti P, Parchi P, Chen SG (2003) Hereditary CreutzfeldtJakob disease and fatal familial insomnia. Clin Lab Med 23:43-64

134. Kretzschmar HA, Giese A, Zerr I, Windl O, Schulz-Schaeffer W, Skworc K et al (1998) The German FFI cases. Brain Pathol 8:559561

135. Zerr I, Giese A, Windl O, Kropp S, Schulz-Schaeffer W, Riedemann C et al (1998) Phenotypic variability in fatal familial insomnia (D178N-129M) genotype. Neurology 51:1398-1405

136. Zarranz JJ, Digon A, Atares B, Rodriguez-Martinez AB, Arce A, Carrera $\mathrm{N}$ et al (2005) Phenotypic variability in familial prion diseases due to the D178N mutation. J Neurol Neurosurg Psychiatry 76:1491-1496

137. Gerstmann J, Sträussler E, Scheinker I (1936) Ueber eine eigenartige hereditaer-familiaere Erkrankung des Zentralnervensystems. Z Ges Neurol Psychiat 154:736-762

138. Giaccone G, Tagliavini F, Verga L, Frangione B, Farlow MR, Bugiani O et al (1990) Neurofibrillary tangles of the Indiana kindred of Gerstmann-Sträussler-Scheinker disease share antigenic determinants with those of Alzheimer disease. Brain Res 530:325-329

139. Yamada $M$, Itoh $Y$, Inaba $A$, Wada $Y$, Takashima $M$, Satoh $S$ et al (1999) An inherited prion disease with a PrP P105L mutation: clinicopathologic and PrP heterogeneity. Neurology 53:181-188

140. Perry RT, Go RC, Harrell LE, Acton RT (1995) SSCP analysis and sequencing of the human prion protein gene (PRNP) detects two different 24 bp deletions in an atypical Alzheimer's disease family. Am J Med Genet 60:12-18 